\title{
The Glass Room: Architecture as a Poetic Emotion
}

\section{Tereza Topolovská}

This paper explores the ways in which Simon Mawer's depiction of architecture and of the character of architect in The Glass Room (200g) establishes connection with the pioneers of Modernist architecture and most notably with Villa Tugendhat situated in Brno. The ambiguous fusion of idea and material, of system and playfulness, of accentuated virility and cool, objective reasoning is clarified only partially by the act of engaging the characters in the dialogue with their real life models and the author's employment of parallelism. It may be understood on the basis of the affinity with the phenomenological conception of dwelling and building of Martin Heidegger whose vision of architecture echoes the persuasion of architects such as Le Corbusier or Ludwig Mies van der Rohe. The aim of this paper is to decipher the aspect of building "as poetic measure taking" and elucidate the firm bond between material and spiritual dimension of architecture mediated with a surprising ease by means of Mawer's fictitious rendition of Czech $20^{\text {th }}$ century history seen through and reflected on the walls of the Glass Room, its metaphorical counterpart.

When Simon Mawer first came to Brno more than eighteen years ago he was particularly interested in the Augustinian Monastery, a place where Gregor Mendel, the famous biologist and the founder of modern genetics, carried out experiments focused on cross breeding. For Simon Mawer, a former teacher of biology turned into novelist, Mendel incarnated a rich source of inspiration, nevertheless, the insight into the life of what should have been the main focus of his novel did not prove as substantial as Mawer thought it would have been. Quite the opposite, he found it "dull", so instead of focussing the novel solemnly on the life of scientific prodigy, Gregor Mendel, the author opted for his fictitious distant relative Lambert, whose genius as well as his handicap turned him into the main protagonist of Mawer's fifth book Mendel's Dwarf (1997). However, Mawer's first visit to Brno was not to remain a single occasion, but it became a starting point of the author's taking a profound interest in Czech culture. Especially the city of Brno (which he visited the most often because of its relative nearness to Italy, where the author lives and 
works in Rome) proved to be far more inspirational than Mawer had thought or hoped for. During his stay there, he visited the then desolate Tugendhat Villa, a pearl of Modernist Architecture and a UNESCO World Heritage Site. The experience of the house moved him so deeply that it triggered the writing and the publication of yet another novel, permeated by Czech culture and history, The Glass Room (2009).

The novel turned out to be Mawer's greatest achievement, a considerable success from both a critical and commercial perspective, earning him his first short-listing for The Man Booker Prize. Mawer himself describes his first encounter with the house as compelling, he could only marvel at the beauty of the villa and the skill of its architect, the famous Ludwig Mies van der Rohe. Nevertheless, it is absolutely indispensable to say that what resulted from this awe is not a biography, but a novel of an unexpected intensity, a novel turned into an apotheosis of art resulting from the infiltration of architecture into the sphere of literature.

Simon Mawer has repeated on numerous occasions that his position is that of a novelist as he stresses in the subtitle of an article which appeared in The Guardian after The Glass Room was published: "I'm a novelist. I don't want to tell the truth. I want to manipulate things as I choose. I want to lie" (Crown). In spite of Mawer's frequent assurances concerning the nature of The Glass Room and in spite of his opting for fictional names of his characters and eluding the implications by employing the Czech non-specific word "Město" in order to name the city in which the novel evolves, the Tugendhat family vehemently denies Mawer's right to write the novel without consulting all of the descendants of the former owners of Villa Tugendhat, Greta and Fritz Tugendhat. Professor Daniela Hammer Tugendhat, their daughter, was visibly distressed by a question concerning the existence of The Glass Room coming from the audience during her lecture "Das Haus Tugendhat und Seine Bewohner" which took place in The Ministry of Culture on $1^{\text {st }}$ October 2012 and said on the account of Simon Mawer: "The Glass Room has robbed us of all, history included. [...] He should have contacted us and consulted us all. [...] He should have left out the family completely or, on the contrary, he should have included it, but should have remained faithful to the true history".

Except for the obvious and wholly justifiable fascination by Villa Tugendhat, Simon Mawer strived to incorporate another exceptional feature into The Glass Room. This feature is the harmonious co-existence of multiple nations in the newly born Czechoslovak Republic. Bilingualism or multilingualism is a recurring motif and a source of refreshment for Mawer's work. According 
to him culture is associated with language and a mingling of cultures and languages leads to an unbelievable cultural enrichment. Most recently it played a prominent role in Mawer's latest novel The Girl Who Fell from the Sky (2012), where the main character, Marian Sutro, joins another character, Viktor Landauer from The Glass Room, in the belief that linguistic membership is insignificant, negligible:

She shrugged, and followed his lead, slipping from one language to the other with that strange facility that she had and her father could never manage. 'The thing is, Papa,' she had told him once, 'for you it's two languages. But it is not for me. For me there's only one language. I simply use the bits of it that are appropriate at the time'. (Mawer, The Girl who Fell from the Sky 6, emphasis in original)

Simon Mawer refers to the linguistic impoverishment, to the meanings lost in translation, through one of the characters of The Glass Room, Tomáš: "The word he used for room, pokoj, can also mean peace, tranquillity, quiet. So when he said the 'glass room' he was also saying 'the glass tranquillity'. Thus one language fails to make itself felt in another" (The Glass Room 333). The English version of The Glass Room operates with words in Czech, German and Russian and logically, the Czech translation of the book is impoverished by the loss of the effect the interplay of the languages engenders. What is more, Lukáš Novák, the author of the critically acclaimed Czech translation, found the universal designation of the Czech word "Město" disturbing and misleading as far as Czech readers were concerned and for the purposes of translation replaced it by "Brno". This decision has certainly strengthened if not helped to establish the firm bond between Villa Tugendhat and the Landauer House from the novel. On the occasion of a book signing held on $17^{\text {th }}$ May 2010 Mawer himself stated that he disagrees with this choice of the translator and would have favoured the maintenance of the formal distance and universality which the toponym "Město" brings to the novel, since what the novel is mostly preoccupied with is the initial optimistic vision of a liberal and open society of the First Czechoslovak Republic which should have been reflected in the unspecified denomination of the city.

What has to be acknowledged is that Mawer's treatment of principal motifs and characters to a certain degree illustrates the practice of drawing from real life events and adjusting them to artistic needs. The author frequently enriches the narration by assertions of real life contemporary artists, who are 
at the same time employed as the inspiration according to which the novel's characters are modelled. When these two groups, one of real life personae and the other of the purely invented, meet (e.g., at the house warming party) the final effect does not affect the novel's integrity, quite the opposite, it is playful and stimulating. The fictitious city "Město" receives the same treatment and to a certain extent it may be compared to the city as featured in Penelope Lively's The City of the Mind (1991). Petr Chalupský in his article "The Urban Pastoral: Hybridisations in Jim Crace's Arcadia" characterizes this work as a novel "introducing the sublime city simultaneously in and out of time, where it becomes, partially, though not exclusively, through the theme of architecture, a manifold metaphor of history and human endeavour and consciousness" (Chalupský 39). In accordance with Dominic Head he argues that the early 1990 s have marked a shift in writing about and understanding the city and certain authors, such as Hanif Kureishi, Angela Carter, Iain Sinclair and Penelope Lively introduced novels where "the realistic aspects of the city intertwine with the fictitious and, in effect, become hardly distinguishable and mutually interchangeable" (Chalupský 39). This perspective is crucially important while taking into consideration the understanding of The Glass Room. It may eventually lead to its understanding as an example of historical revisionism fictionalizing the history of Tugendhat Villa and the overall historical development of the Czech Republic in the twentieth century. This viewpoint was favoured by Anna Grmelová who understood The Glass Room primarily as a brilliant evocation of the spirit of interwar Czechoslovakia and also: "[...] a rhapsody on the Glass Room of the Landauer Villa and [...] also a rhapsody on the ideals of interwar Czechoslovakia, of the First Czechoslovak Republic" (Higgins). It is primarily in this light that the novel should be read and interpreted, as an exceptional work of art, not as a biographical attempt to map the history of a house and a family.

What is the Glass Room to which the novel owes its title? Technically speaking, the Glass Room is a unique room covering the whole floor of Villa Landauer without any barriers dividing the space according to the functions. What is more, most of its walls are replaced by gigantic floor-toceiling panoramic windows, so that the interior and the exterior are visually connected. This effect is even enhanced by the sinking windows which can be retracted to the floor. The Glass Room is a continuum of light and space, a realm of reason and lucidity, of unconstrained freedom, of immense possibilities. Together with the rest of the villa it functions as a metaphor of the new thinking, pure and unspoilt, of society of unlimited possibilities and 
unimportant borderlines freed of all kinds of persecution. The whole villa is exceptional concerning its proportions, its particular treatment of space and materials and its innovative division of functions. Nevertheless, it is the Glass Room where the heart of the house beats; from where its uniqueness springs. It is not a simple setting of the story, but it becomes its main protagonist either appearing or being mentioned in every single chapter of the novel. Characters come and go, the political situation changes and history passes under its cool gaze. It does not act as a part of the characters' histories, but it invites them to become parts of its own colourful and rich history. And not only the characters but the whole history yields to the shimmering walls of the Glass Room, as Ian Sansom states in his article in The Guardian "Design for Living" "history doesn't take place outside it, it comes to it". The motif of its troubled destiny is foreshadowed in the Prologue depicting Liesel Landauer's return to the villa in the late 1960 s:

The slow slide of the pane downwards as though to remove the barrier that exists between reality and fiction, the fabricated world of the living room and the hard fact of snow and vegetation. There is a pause during which the two airs stand fragile and separate, the warmth within shivering like a jelly against the wall of cold outside. And then this temporary equilibrium collapses so that winter with a cold sigh intrudes, and presumably, their carefully constructed, carefully warmed interior air is dispersed into the outside world. (The Glass Room 5)

In this case it is the air from the inside which after a short interval of "equilibrium", of opposition to the "wall" of the cold air from the outside, vanishes into the outside world as the Landauers, and as the young Republic were swept away by lethal tides of the Second World War.

The Glass Room functions as an extended metaphor of the period and it also frames the history of Viktor and Liesel, a newly-wed couple, both descendants of Brno upper-class German-speaking families of industrialists, and willing to be modern body and soul. They want to express their split with the past by constructing an exceptional house: "[...] this clinging to the past. This is everything our new house will not be!" (Mawer, The Glass Room 9). Their house should become the incarnation of their belief in progress, in future, in the emergence of modern society which would not be encumbered with prejudice and imposition, but would replace these by reason and democratic values. Despite the enormous cost of their villa, Viktor and Liesel do not wish 
to manifest their fortune and their privileges. Their intentions have a deeper philosophical significance.

The whole essence of the Glass Room is reason. That is what Viktor thinks, anyway. For him, it embodies the pure rationality of a Greek classical temple, the austere beauty of a perfect composition, the grace and the balance of a painting of Mondrian. [...] There is nothing convolute, involute, awkward or complex. Here everything can be understood as a matter of proportion and dimension. (Mawer, The Glass Room 137)

The fictitious author of "the fabricated world of the living room" is Rainer von Abt, a mercurial character whom Liesel and Viktor met in Venice "the most ornamental city in the world" (Mawer, The Glass Room 24) which is at the same time the triumph of technological skill of its builders. They immediately realize that they follow the same ideals such as futuristic belief in technology, in speed (which is repeatedly emphasized by Viktor's handling of the car or Rainer's treatment of the speed boat), in the possibility of planning the future and in all encompassing citizenship of the whole world. No obstacles should prevent humans from the free creation and suppress continuous and inevitable progress. Rainer von Abt is a man with crystal clear vision and firm resolutions to turn the world into a better place. Although he mentions his contemporaries and actually calls himself a disciple of Adolph Loos, he is the incarnation of a perfect architect resulting partially from the process of incorporating the traits of several real life architects, most prominently the famous German architect Ludwig Mies van der Rohe, the author of the design of Villa Tugendhat. What the fictitious Rainer von Abt and real life Ludwig Mies van der Rohe share is the way of expressing themselves. They both express their ideas and views principally through their work, otherwise their speech is sparse and closer to the series of dicta. The work of Mies van der Rohe is based heavily on philosophical foundations, which is obviously echoed by the views of Rainer von Abt. It was Thomas Aquinas's "adaequatio rei et intellectus" (Blaser 9) which dominated Mies van der Rohe's conception of architecture, he saw the technological progress as an inevitable process defining individual epochs and providing the architects with the structure on which they should concentrate. Having enriched architecture with ultimately simple, archetypal forms Mies was a great admirer if not continuator of the thoughts of Francis Bacon whose connection of science with art and utility he treasured. Francis Bacon has himself declared in his Essays "[h]ouses are 
built to live in, and not to look on; therefore let use be preferred before uniformity, except where both may be had" (Bacon 115). Quite naturally, when Thomas Case wrote preface to The Advancement of Learning and The New Atlantis he compared Bacon attempting the systematization of all human knowledge to "a great architect, conceiving a vast plan, distributing it into its proportionate parts, and so giving each man his appropriate chamber, in which to direct his mind to the right object in its real relations to the whole of things" (Case 15). Mies was also familiar with Romano Guardini, one of the most significant figures of German Christian Personalism. While constructing Villa Tugendhat he materialized his belief that "large spaces provide freedom" (Tugendhat - Ludwig Mies van der Rohe's Commision in Brno 12). With regard to Rainer von Abt it is also necessary to mention the legacy of Theo van Doesburg, a multi-talented Dutch artist whose

greatest influence lay in the area of architecture and design. $[\ldots]$ he took the flat, geometric painting of De Stijl group and burst it out into the third dimension. [...] In the drawings perspective is ambiguous; walls are no longer supporting structures but floating, intersecting planes of primary colour; rooms are not static boxes but conceptual spaces hovering in the air. (Mawer, Diagonal Lives)

Rainer von Abt's enigmatic sentences may be deciphered with reference to Doesburg: "Stability is the last thing I want. This house must float in light. It must shimmer and shine. It must not be stable" (Mawer, The Glass Room 47 ) or "[s]teel will be as translucent as water. Light will be as solid as walls and walls as transparent as air. I conceive of a house that will be unlike any other, living space that changes functions as the inhabitants wish, a house that merges seamlessly into the garden outside, a place that is at once of nature and quite aside from nature..." (Mawer, The Glass Room 43). Besides this exceptional artist, von Abt mentions Le Corbusier and his technological conception of buildings which should become "machines for living" and bears certain traces of Adolph Loos whose idea of cross presented originally in the famous lecture turned into essay "Ornament and Crime" von Abt readily presents as proof of the human dimension of his work. Besides defining the first ornament, the cross which was "erotic in origin. The first work of art, the first artistic act which the first artist, in order to rid himself of his surplus energy, smeared on the wall. A horizontal dash: the prone woman. A vertical dash: the man penetrating her" (Loos 19). Adolph Loos also calls for the 
rejection of ornaments which spoil the beauty and burden the buildings as well as investors with unnecessary financial requirements.

Nevertheless, the inspiration and fascination by the founders of Modernist architecture does not suffice in order to interpret the ambiguous nature of the character of Rainer von Abt. On one hand his personality frequently displays vibrant vitality and his connection with the matter is enhanced by the author's allusions to robustness and virility which at times verges on the "look of a boxer in the early part of his career" (Mawer, The Glass Room 12), on the other hand he seems surrounded by a delicate halo of philosophical power. However, what slightly challenges his position of a spiritual authority is the obvious sexual attraction between him and Liesel Landauer. And although it is never consummated, the tension is omnipresent and surprisingly more apparent than the attraction between Liesel and Viktor, her husband. That sexuality plays a crucial role in von Abt's creation becomes clear when he reacts to Liesel's judging his design cold. There he echoes the teaching of Adolph Loos: "This is the first work of art: the woman who lies down. [...] And this. This is the man who penetrates her. The result is the rectangular cross that underpins all my art. What could be warmer than that?" (Mawer, The Glass Room 24) The paradoxical interplay of spiritual and material, organic and inorganic, involute and convolute, darkness and light permeates the whole world of the novel and nourishes Mawer's creation.

Accordingly, Liesel's pregnancy is mirrored in the construction of the house, both processes following the path of perfection, with both final "products" incarnating beauty, joy and hope. Liesel's pregnancy is thus celebrated and elevated upon the level of pure physicality and the construction of the house acquires a new dimension as well. "Nature seemed suspended in this icy season, but still things grew - the child in Liesel's womb, the house in Rainer von Abt's mind. The one convolute, involute, curved and complex - there are no straight lines in nature - the other simple and linear" (Mawer, The Glass Room 44). The successful completion of the house is paralleled by the painless delivery of Ottilie, and both seem to be echoing the optimistic belief in a better future, full of growth and development. "In April, while the frame grew, the baby was born" (Mawer, The Glass Room 45).

The parallelism employed in order to express the continual processes of conceiving a child and constructing a house may throw light on the close-knit connection between the architect and the matter. Anna Hogenová, whose lectures on Phenomenology and its possible application on the contemporary social paradigm, ${ }^{1}$ studies the position and respectability of the architect: 
[... That is why the architect abounds with such philosophical power, he is joint with the origin, with arché. 'Tekton' is a Greek word derived from technai, that is creation. The architect returns to the dignity of the origin in a philosophical form, which is a hardened motion of 'music', the result is a building. This melody is harmonia afanes, it is the harmony of the spheres, it is the invisible harmony, testifying to the origin, to the dignity of origin! (Hogenová)

Martin Heidegger has immensely enriched the ongoing discussion concerning the fundamental concepts of movement, space and its inhabitation by their profoundly and fundamentally human dimension which he describes in essays "... Poetically, Man Dwells..." and "Building Dwelling Thinking" in Poetry, Language, Thought. What he calls "dwelling" is a poetic process. The house is accordingly seen as the fulfilment of human aspirations, something which springs from our innermost needs, and founds and nurtures humanity. ${ }^{2}$ Heidegger's theory applied to Rainer von Abt sees him as the incarnation of a poet capable of understanding the deep significance of a building and erecting houses which correspond to the needs of human existence. The architect - "poet" is thus able to mediate "dwelling" to others.

Man does not dwell in that he merely establishes his stay on the earth beneath the sky, by raising growing things and simultaneously raising buildings. Man is capable of such building only if he already builds in the sense of the poetic taking of measure. Authentic building occurs so far as there are poets, such poets as take the measure for architecture, the structure of dwelling. ( "... Poetically, Man Dwells..." 276)

Architects, poets, should build by "poetic taking of measure", their designs should reverberate with their ideas, hopes, dreams, wishes and the persuasions of their clients as well as their own projected into the material. Le Corbusier, one of the greatest and also most highly influential architects and innovators of $2 \mathrm{O}^{\text {th }}$-century architecture expressed his view on the connection of architecture and thought in an essay "Architecture, Pure Creation of the Mind." There he defines architecture as a material expression of thought which unlike literature or music does not reveal itself solely by means of sound or words. The shapes which are employed are described as "a mathematical creation of your mind. They are the language of Architecture. By the use of inert materials and starting from conditions more or less utilitarian, you have established certain 
relationships which have aroused my emotions. This is Architecture" (Le Corbusier 203, emphasis in original).

Echoing this vision of architecture the fictitious von Abt declares "I I work with nothing but ideas"” (Mawer, The Glass Room 22) and rejects the label of "an architect":

'I repeat,' replied Rainer von Abt, 'I am a poet of space and form. Of light' - it seemed to be no difficulty at all to drag another quality into his aesthetics - 'of light and space and form. Architects are people who build walls and floors and roofs. I capture and enclose the space within'. (Mawer, The Glass Room 16)

What Rainer von Abt desires is to give a shape and proportion to the ideas the Landauers and himself worship. He incarnates an emblematic example of explorer of harmony and balance, he is a unique example of persona capable to capture the space within the walls of rooms and buildings, to imagine and design the boundaries from which the space may start "presencing". Rainer von Abt shows a rare understanding for the needs, beliefs, ideas and wishes of his clients, as he shares these with them. He proposes to the Landauers to design a whole new way of life and he succeeds in it. "II wish,' he was telling them, 'not just to design a house but to create a whole world. [...] I will design you a life. Not a mere house to live in, but a whole way of life" (Mawer, The Glass Room 28). His proposition certainly is directive, almost manipulative. That does not prevent Viktor and Liesel to relish and revel in the beauty of the exceptional building which is the work of art but above all their home.

Liesel and Viktor stood and marvelled at it. It had become a palace of light, light bouncing off the chrome pillars, light refulgent on the walls, light glistening on the dew in the garden, light reverberating from the glass. It was though they stood inside a crystal of salt. 'Isn't it wonderful,' she exclaimed, looking round with an expression of amazement. 'You feel so free, so unconstrained. The sensation of space, of all things being possible. Don't you think it is wonderful, Viktor? Don't you think that Rainer has created a masterpiece for us? (Mawer, The Glass Room 65)

What The Glass Room excels in is not mere evocation of the spirit of the period or skilful weaving of allusions to contemporary artists, places and 
historical events into the fabric of the novel. It succeeds in the presentation of architecture not as a mere backdrop, but as self-contained artistic expression. Despite the notable number of various extra-textual references, the result is a harmonious and consistent attempt to underline the fact that architecture is not a haphazard assemblage of separate elements but all encompassing process which in words of Le Corbusier gives "a living unity to the work" (Le Corbusier 214) and also proves that "[a]rchitecture only exists when there is poetic emotion" (Le Corbusier 214).

The Glass Room has sparked an interest in the personality of the architect, who, besides Nature, shapes the face of the world we perceive. We may search for answers to the questions awakening our curiosity: To which extent is his or her personality projected in the final design, how does he or she determine the overall symbolic expression of the building? We tend to perceive Space as something obvious, clear, yet we encounter immense difficulties when we strive to describe it, to imagine it, to plan it. The uniqueness of the architect resides in the fact that he or she is able to capture the space within the walls of rooms and building, to "make room" for the space to fill in. The question which logically follows such a characteristic concerns the capacity of a novelist to capture the fleeting essence of Space or the highly ambiguous nature of architectural creation. The Glass Room proves that it is possible and that these two artistic expressions are closer than may seem. The persuasive and effective interweaving of architecture and literature in fact only continues the journey the author has embarked on by Mendel's Dwarf where science replaces architecture in its position of unexpected choice and treatment of subject matter. Simon Mawer surmounts the opposition by stating:

$[\ldots]$ just as an artistic creation lives in the mind of its creator, so too does a scientific idea. We labour under the illusion that discoveries and ideas lie somewhere out there in nature - but in truth the science is in the discoverer's head. [...] There is little difference between this and artistic vision. $[\ldots]$ The essence is the idea and the enquiry. 'What if?' is the question posed in both literature and science. ("Science in Literature")

It is exactly this "What if?" which vitalizes fiction and energizes its artistic potentiality. Architecture demonstrates readily the merging of abstract ideas with rational core and material form as well as fiction, besides the construction of "castles in the air" (Ibsen 135), and has to rely on construction which is more or less cut with the precision of surgical strike. Ian McEwan summarized his 
view on novels by stating: "I think of my novels in architectural terms. You have to enter at the gate, and this gate must be constructed in such a way that the reader has immediate confidence in the strength of the building" (McEwan). This dictum is yet another proof of the osmosis of artistic expression to which The Glass Room points with an understated elegance of an exceptional Modernist building.

\section{Works Cited}

Bacon, Francis. "Of Building." The Complete Essays of Francis Bacon including The New Atlantis and Novum Organum. New York: Washington Square Press, 1963 .

Bachelard, Gaston. The Poetics of Space. 1958. Boston: Beacon Press, 1994.

Blaser, Wener. Mies van der Rohe. London: Thames and Hudson Ltd, 1972. Case, Thomas. "Preface" The Advancement of Learning and The New Atlantis. London: Oxford University Press, 1913.

Chalupský, Petr. "The Urban Pastoral: Hybridisations in Jim Crace's Arcadia." Litteraria Pragensia. Vol. 20, Issue 40, December 2010: 38-54.

Crown, Sarah. "A Life in Books - Simon Mawer," The Guardian 3 October 2009. 1 November 2010 <http://www.guardian.co.uk/culture/2009/oct/o3/ simon-mawer-life-in-books>.

Hammer-Tugendhat, Daniela. "The Tugendhat House and its Inhabitants"; "Das Haus Tugendhat und Seine Bewohner" lecture pronounced on the occasion of the cycle of Pražské rozhovory organized by Das Österreichische Kulturforum Prag, 1 October 2012.

Heidegger, Martin. “... Poetically, Man Dwells... .” Philosophical and Political Writings. Ed. Manfred Stassen. 1951. New York: The Continuum International Publishing Group, 2006.

---. "Building Dwelling Thinking." Poetry, Language, Thought. Transl. Albert Hofstadter. New York: Harper and Row, 1975.

Higgins, Bernadette. "Czech History Through a Glass Darkly." Radio.cz 22 November 2009. 14 March 2010 <http://www.radio.cz/en/section/books/ czech-history-through-a-glass-darkly>.

Hogenová, Anna. How do we care for our soul? [Jak pečujeme o svou duši??] Praha: Univerzita Karlova v Praze, Pedagogická fakulta, 2008.

Ibsen, Henrik. The Master Builder. 1892. Whitefish, Montana: Kessinger Publishing, 2010.

Le Corbusier. "Architecture, Pure Creation of the Mind" Towards a New Architecture. 1923. New York: Holt, Rinehart and Winston, 1976. 
Loos, Adolph. "Ornament and Crime." Ornament and Crime. 1910. Riverside, California: Ariadne Press, 1997. 19-24.

Mawer, Simon. Mendel's Dwarf. 1997. London: Abacus, 2011.

---. "Science in Literature." 2003. Nature. March 2005. 6 November 2012. <http://www.simonmawer.com/ScienceandLiterature.htm>.

---. The Glass Room. London: Little, Brown, 2009.

--.." Diagonal Lives." The Guardian. 23 January 2010. 1 December $2010<$ http:// www.guardian.co.uk/artanddesign/2010/jan/23/theo-van-doesburg-avantgarde-tate>.

---. The Girl Who Fell from the Sky. London: Little Brown, 2012.

McEwan, Ian. "Ian McEwan." The Guardian 22 July 2008. 11 August 2012 <http://www.guardian.co.uk/books/2008/jun/12/ian.mcewan>.

Mies van der Rohe, Ludwig. Building. [Stavění.] Praha: Arbor Vitae, 2000.

Patočka, Jan. "Fifth Essay: Is technological Civilization Decadent, and Why?" Heretical Essays in the Philosophy of History. Transl. Erazim Kohák. Ed. James Dodd. Chicago and La Salle, Illinois: Open Court Publishing Company, 1996.

Purdon, James. "The Glass Room by Simon Mawer." The Observer 25 April 2010. 4 October 2010 <http://www.guardian.co.uk/books/2010/apr/25/ the-glass-room-simon-mawer $>$.

Sansom, Ian. "Design for living." The Guardian. 24 January 2009. 1 November 2010 <http://www.guardian.co.uk/books/2009/jan/24/simon-mawer-theglass-room $>$.

Tugendhat - Ludwig Mies van der Rohe's Commision in Brno. Ed. Iveta Černá, Dagmar Černoušková. Brno: Brno City Museum, 2011. 